\title{
Honey as a bioindicator for environmental pollution with $\mathrm{SO}_{2}{ }^{1}$
}

\author{
Maja PONIKVAR*, Jože ŠNAJDER, Borka SEDEJ \\ Jožef Stefan Institute, Jamova 39, SI-1000 Ljubljana, Slovenia
}

Received 9 July 2004 - revised 19 October 2005 - accepted 4 November 2005

Published online 7 July 2005

\begin{abstract}
Honey was proven to be a highly sensitive bioindicator for estimation of the environmental pollution with $\mathrm{SO}_{2}$. A bee monitoring net consisting of 32 apiaries and covering an area of about $700 \mathrm{~km}^{2}$ was configured surrounding the Šoštanj coal-fired power plant. The results of investigations revealed that the amount of sulphate determined in honey from this area correlated with total yearly emissions of $\mathrm{SO}_{2}$ observed by an electronic monitoring. When exhaust gases at the power plant were purified, a corresponding decrease in the amounts of sulphate in honey was observed. The proposed bee monitoring net is an example of using biomonitoring for tracing environmental pollution, which could be also applied to estimate the impact of $\mathrm{NO}_{\mathrm{x}}$ gases or to trace other pollutants.
\end{abstract}

$\mathrm{SO}_{2}$ / pollution / biomonitoring / bioindicator / honey

\section{INTRODUCTION}

The Šoštanj coal-fired power plant with its $745 \mathrm{MW}$ installed electrical power is the largest power plant in Slovenia. The power plant consists of three units as follows: B1-3 with $135 \mathrm{MW}$, B4 with $275 \mathrm{MW}$ and B5 with $335 \mathrm{MW}$ installed electrical power. The dominant component of the exhaust gases for this type of facility is $\mathrm{SO}_{2}$. A marked decline in the surrounding pine forest has been observed during the first year of operation of the power plant. An improvement program has been established with the objectives of building up the air pollution monitoring system and constructing purifying facilities for the exhaust gases.

The implemented immission monitoring system consists of seven stationary immission measuring stations, which continuously measure the $\mathrm{SO}_{2}, \mathrm{NO}_{\mathrm{x}}$ and $\mathrm{O}_{3}$ concentrations and the meteorological data. The measured concentrations of the harmful gases assure fast response information on how much the air travelling over the location of the immission station is polluted. Such information is very useful for the control of the purifying facilities but does not necessarily give realistic information about the impact of the harmful gases on the area around the power plant.

Biomonitoring is a valuable assessment tool that is receiving increased attention in air quality monitoring programs. In a general sense, biomonitoring may be defined as the use of organisms/materials to obtain quantitative information on certain characteristics of the biosphere (Wolterbeek, 2002). The quantitative information may be defined as a measure of integrated exposure of exposed organisms/ materials over a certain amount of time (Smodiš and Bleise, 2002).

Honey bees (Apis mellifera L.) and their products have been used for biomonitoring the distribution and impact of various environmental pollutants including trace elements, heavy

\footnotetext{
* Corresponding author: maja.ponikvar@ijs.si
}

${ }^{1}$ Manuscript editor: Gudrun Koeniger 
metals, radionuclides, pesticides and organic pollutants (Bromenshenk et al., 1991; Barišić et al., 2002). Honey bees readily fly up to $4 \mathrm{~km}$ in all directions from their apiary and thus have access to an area of about $50 \mathrm{~km}^{2}$. They therefore represent an excellent system of small samplers (Hoopingarner and Waller, 1993). It is usually assumed that honey does not contain sulphate whereas honeydew has a high sulphate amount, in some cases $73 \mathrm{mg} / 100 \mathrm{~g}$, expressed as sulphuric acid (Singhal et al., 1997). Schuette and Triller (1938) reported results on the analyses of United States honeys; light honeys contained 36 to $108 \mu \mathrm{g} \mathrm{S} / \mathrm{g}$ and dark 56 to $126 \mu \mathrm{g} \mathrm{S} / \mathrm{g}$.

Being specifically composed of particularly high amounts of various sugars, honey represents a distinctive type of sample (White Jr., 1975). Total sulphur in honey has been determined after total decomposition of honey with titration with $\mathrm{BaCl}_{2}$ (Schuette and Triller, 1938), after dissolution of honey in water by $\mathrm{X}$-ray fluorescence spectrometry (XRF) and total reflection X-ray fluorescence spectrometry (TXRF) (Kump et al., 1996) and as free sulphate after prior extraction by ion-chromatography (Del Nozal et al., 2000). Direct comparison between the amounts of total sulphur and water-soluble free sulphate in honey has not been reported.

The aim of our investigations was to develop a monitoring system for determining the impact of $\mathrm{SO}_{2}$ from the Šoštanj coal-fired power plant and similar combustion facilities on the surrounding area using the honey bees or their products as bioindicators.

\section{MATERIALS AND METHODS}

All reagents were of analytical grade and all solutions were prepared using double-distilled water.

\subsection{Sampling and homogenisation}

Honey bees (considered to be Apis mellifera carnica) and their products were used throughout the study.

Initially two groups of six honey bee colonies were selected. One was located in Zavodnje, in an area known to be polluted by the Šštanj coal-fired power plant and the other was located $100 \mathrm{~km}$ away, in Poljanska dolina, an area without local $\mathrm{SO}_{2}$ pollution but at the same height above the sea level (approximately $800 \mathrm{~m}$ ). Both locations were similar in topography and pasture conditions. To exclude the possibility of differences between these two groups of colonies, the control colonies were taken from Zavodnje and set at the location in Poljanska dolina so all the bees came originally from Zavodnje.

The samples of pollen (collected from the cells), honey bees and honey analysed during the first years of the study (in 1993, 1994 and 1995) were taken in equal time intervals during the pasture season. The samples of pollen were dried at $45^{\circ} \mathrm{C}$ and samples of honey bees at $105^{\circ} \mathrm{C}$ in a laboratory oven (Instrumentaria, ST-01/02) and then homogenised by grinding in an agate ball mill.

Samples of honey (from 1995 on) were collected at the end of the pasture season. Usually more than one extraction was performed on each observed apiary during the season (from May to August). For that reason, the samples were composed from equal volumes of honey obtained during each extraction. At least $200 \mathrm{~mL}$ of composite sample was formed that way. Samples were placed in polyethylene bottles and before analysis were homogenised by heating to $40{ }^{\circ} \mathrm{C}$ with subsequent stirring.

\subsection{Sample preparation}

\subsubsection{Total decomposition}

One $\mathrm{g}$ of dry bee tissue, $1 \mathrm{~g}$ of pollen, or $10 \mathrm{~g}$ of honey was weighed into a platinum dish, made alkaline by addition of $50 \%$ aqueous $\mathrm{NaOH}$ and dried on a sand bath. The dry remains of each sample were fused by addition of $6 \mathrm{~g}$ of solid $\mathrm{KNaCO}_{3}$ (Bock, 1979). The melt was dissolved by addition of conc. $\mathrm{HCl}$.

\subsubsection{Dissolution in water}

A $15 \mathrm{~g}$ sample of honey was weighed into a $100 \mathrm{~mL}$ Erlenmayer flask with a stopper. Thirty $\mathrm{mL}$ of distilled water was added and shaken for 2 hours on a laboratory shaker. The dissolved sample was transferred into a $100 \mathrm{~mL}$ volumetric flask and diluted with water to the mark. The resultant samples were first filtered through $589^{3}$ blue ribbon filter paper) and then through filter units FP 30/0.45 CA.

\subsection{Analysis}

\subsubsection{Gravimetric method}

The amount of sulphate was determined gravimetrically by precipitation with a $10 \%$ aqueous solution of $\mathrm{BaCl}_{2}$ in a strongly acidic $(\mathrm{HCl})$ media (Vogel, 1978).

\subsubsection{Potentiometric precipitation titration}

The amount of sulphate was determined in a $25 \mathrm{~mL}$ aliquot of each sample by titration with 
$0.005 \mathrm{M} \mathrm{Pb}\left(\mathrm{ClO}_{4}\right)_{2}$ prepared by dilution of $0.1 \mathrm{M}$ $\mathrm{Pb}\left(\mathrm{ClO}_{4}\right)_{2}$. The end-point of titration was determined potentiometrically (Ross and Frant, 1969) with an indicator lead ion selective electrode $(\mathrm{Pb}-$ ISE) (Orion 94-82) and a reference electrode (Orion 90-02) on an Orion 960 autochemistry system. Constant ionic strength was achieved by addition of $1 \mathrm{~mL}$ of $5 \mathrm{M}$ aqueous $\mathrm{NaClO}_{4}$. The interference of fluoride was removed by addition of $1 \mathrm{~mL}$ of $0.02 \mathrm{M}$ aqueous $\mathrm{H}_{3} \mathrm{BO}_{3}$ (Selig, 1970). The solubility of $\mathrm{PbSO}_{4}$ in water was minimized by addition of $25 \mathrm{~mL}$ of dioxane to the samples.

\subsubsection{Photometric precipitation titration}

A $20 \mathrm{~mL}$ aliquot of each sample was adjusted to pH 3 with $1 \% \mathrm{HClO}_{4}$ prepared by dilution of $60 \%$ $\mathrm{HClO}_{4}, 0.5 \mathrm{~mL}$ of a $0.2 \%$ solution of Thorin was added and diluted with acetone to $50 \mathrm{~mL}$ to decrease the solubility of $\mathrm{BaSO}_{4}$ (Mooibroek, 1978). Air bubbles were removed by shaking the sample solution in an ultrasound bath (Iskra UZ 4R). The amount of sulphate was determined by titration with $0.02 \mathrm{M}$ aqueous $\mathrm{Ba}\left(\mathrm{ClO}_{4}\right)_{2}$. The end-point of titration was determined photometrically using Mettler titrator (DL70ES) and Mettler phototrode (DP 550). The method was developed in 1995 in response to the installation of the purifying units at the power plant, which resulted in decreased amounts of sulphate in honey.

\subsection{Bee monitoring net and electronic monitoring}

In order to assure reliable coverage of the $\mathrm{SO}_{2}$ polluted area surrounding the Šoštanj coal-fired power plant, a bee monitoring net of apiaries, selected from existing apiaries in this area, was configured to cover an area of about $700 \mathrm{~km}^{2}$. The locations of these apiaries and the main wind directions in this area are outlined in Figure 1.

As presented by Figure 1 the denser location of apiaries (sampling locations) was selected in the directions of the main pollutant transport in this area, which is directed north and swings in between the northwest and northeast directions. The other significant direction is the southwest. These locations also represent more densely inhabited regions.

Regular monitoring was carried out from 1994 to 2001. In 1994 and 1995 the net consisted of eight and twelve apiaries, respectively, located in the area surrounding the Šoštanj power plant and a reference apiary located at a non-polluted location. In 1996 the net was increased to 10 apiaries and in 1997 to 27 apiaries. In the last four years of the monitoring the net consisted of 31 to 33 apiaries.

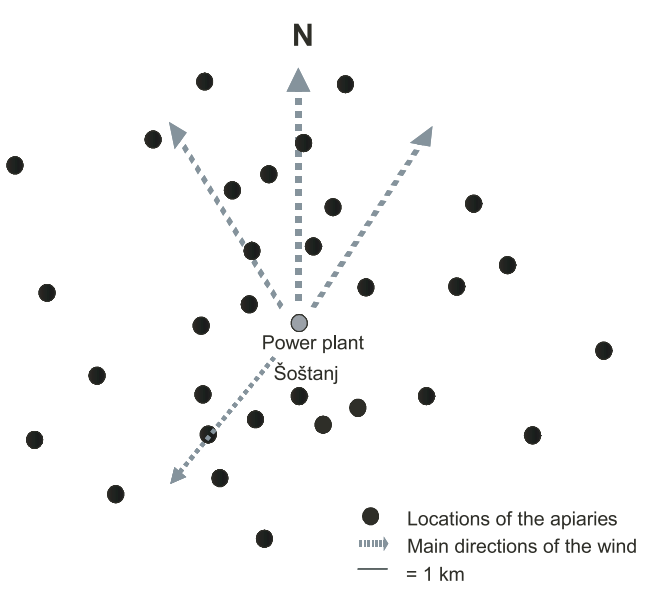

Figure 1. Locations of the apiaries in the bee monitoring net and the main wind directions.

The effect of coal-fired Šoštanj power plant on the environment was concurrently monitored with the Šoštanj power plant Environmental Information System (EIS), which covers immission, emission and hydrological measurements. The system integrates seven stationary immission measuring stations located in its surrounding area, which continuously measure the $\mathrm{SO}_{2}, \mathrm{NO}, \mathrm{NO}_{2}, \mathrm{NO}_{\mathrm{x}}$ and $\mathrm{O}_{3}$ concentrations in the air and the meteorological data (wind speed and direction, air temperature, relative air humidity) (Milan Vidmar Elektroinstitute, 2001).

\section{RESULTS AND DISCUSSION}

The emphasis in the preliminary investigation starting in 1992 was to find the most suitable indicator and parameter for estimating environmental pollution with $\mathrm{SO}_{2}$.

Initially the population dynamics (total brood area and mass of emerging and foraging bees) of two groups of honey bee colonies were determined monthly. However, the results obtained revealed that the population dynamics of colonies located in Zavodnje were not significantly different from those in the non-polluted area in Poljanska dolina. This indicated that this was not an appropriate parameter to monitor local pollution with $\mathrm{SO}_{2}$.

For that reason samples of honey and bee tissue were taken in 1993 and samples of honey and pollen in 1994 in order to investigate whether the amount of total sulphur in samples 
Table I. The amounts of total sulphur determined (in the form of $\mathrm{SO}_{4}{ }^{2-}$ ) in samples of honey, bee tissue and pollen collected in a non-polluted (Poljanska dolina) and $\mathrm{SO}_{2}$-polluted area (Zavodnje) (mean $\pm 1 \mathrm{SD}$ )

\begin{tabular}{|c|c|c|c|c|c|c|c|c|}
\hline \multirow[b]{3}{*}{ Substrate } & \multicolumn{8}{|c|}{ Mean amount $\mathrm{SO}_{4}^{2-}(\%)$} \\
\hline & \multicolumn{4}{|c|}{ Year 1993} & \multicolumn{4}{|c|}{ Year 1994} \\
\hline & Zavodnje & $\mathrm{n}$ & Poljanska dolina & $\mathrm{n}$ & Zavodnje & $\mathrm{n}$ & Poljanska dolina & $\mathrm{n}$ \\
\hline Honey & $0.032 \pm 0.009$ & 6 & $0.016 \pm 0.004$ & 4 & $0.020 \pm 0.004$ & 3 & $0.008 \pm 0.003$ & 3 \\
\hline Bee tissue & $0.90 \pm 0.19$ & 8 & $0.79 \pm 0.22$ & 7 & - & - & - & - \\
\hline Pollen & - & - & - & - & $0.05 \pm 0.01$ & 3 & $0.12 \pm 0.01$ & 3 \\
\hline
\end{tabular}

from Zavodnje would differ significantly from the amount of sulphur from Poljanska dolina. Table I shows the amounts of $\mathrm{SO}_{2}$ detected in the honey, pollen and bee samples taken from Zavodnje and Poljanska dolina.

Analysis of these results showed that, of the samples selected, honey was the most promising bioindicator for estimating the environmental load with $\mathrm{SO}_{2}$, i.e. the ratio between the amount of sulphate determined in the samples from polluted versus non-polluted area was highest in the honey samples. A significance test for comparison of the means of two samples (Miller and Miller 1993) additionally confirmed that the differences between mean amounts of sulphate determined in honey (in 1993 and 1994) and pollen (in 1994) in a nonpolluted and $\mathrm{SO}_{2}$ polluted area were significant at the 0.05 level while this was not the case for the samples of bee tissue (in 1993).

In the first year of honey pollutant monitoring using a net of apiaries in 1994 (which was also the last year in which the power plant operated without exhaust gas purifying facilities) the mean amount of sulphate determined in samples from the existing net was $355 \mu \mathrm{g} \mathrm{SO}_{4}{ }^{2-} / \mathrm{g}$ $\left(\mathrm{n}=8, \mathrm{SD}=224 \mu \mathrm{g} \mathrm{SO}_{4}{ }^{2-} / \mathrm{g}\right)$. The maximum determined amount exceeded $730 \mu \mathrm{g} \mathrm{SO}_{4}{ }^{2-} / \mathrm{g}$. This amount is around ten times higher than the natural amount of sulphate in honey (Schuette and Triller, 1938). High SD indicated wide range of amounts of $\mathrm{SO}_{4}^{2-}$ determined in honey thus high sensitivity of honey as bioindicator for $\mathrm{SO}_{2}$ emissions was additionally proven.

Before the beginning of the 1995 pasture season, the first exhaust gas purifying facility on the B4 unit of the power plant was put into operation. Figure 2 illustrates amounts of sulphate determined in honey collected in seasons
1994 and 1995 at the polluted location, Zavodnje, and the non-polluted location, Poljanska dolina, compared to the total emission of $\mathrm{SO}_{2}$ in these years. In order to enable comparison with the results obtained in 1994 the samples were taken and analysed in equal time periods.

Total emission of $\mathrm{SO}_{2}$ in 1995, as measured by electronic monitoring, decreased by $36 \%$ compared to 1994 . The observed decrease was due not only to the operational activity of the power plant, but mainly to the new exhaust gas purifying facilities on the B4 unit. By using a significance test for comparison of the means of two samples (Miller and Miller 1993) it was shown that the differences in the amounts of sulphate determined in honey from a non-polluted and $\mathrm{SO}_{2}$ polluted area in these years were significant at the 0.05 level. When the ratio of the amount of sulphate determined in honey from Zavodnje against the amount determined in Poljanska dolina was calculated it was found to be 2.5 for year 1994 and 1.6 for year 1995 . This corresponds to a $36 \%$ decrease in the sulphate amounts in honey, the same as that identified by electronic monitoring (36\%).

The second purifying facility (on the B5 unit) was put into operation at the beginning of 2001. A $41 \%$ decrease in the total yearly $\mathrm{SO}_{2}$ emission was determined by electronic monitoring that year in comparison to the previous year. The bee monitoring net promptly detected the decreased $\mathrm{SO}_{2}$ emission. The calculated mean sulphate concentration for the entire net of 32 apiaries in the area surrounding the Šoštanj power plant for this year was $117 \mu \mathrm{g}$ $\mathrm{SO}_{4}{ }^{2-} / \mathrm{g}$ for year $2001(\mathrm{n}=32, \mathrm{SD}=73 \mu \mathrm{g}$ $\left.\mathrm{SO}_{4}{ }^{2-} / \mathrm{g}\right)$ and $182 \mu \mathrm{g} \mathrm{SO}_{4}{ }^{2-} / \mathrm{g}(\mathrm{n}=33, \mathrm{SD}=89 \mu \mathrm{g}$ $\mathrm{SO}_{4}{ }^{2-} / \mathrm{g}$ ) for year 2000 . This represents a $36 \%$ decrease in the amount of sulphate and agrees 


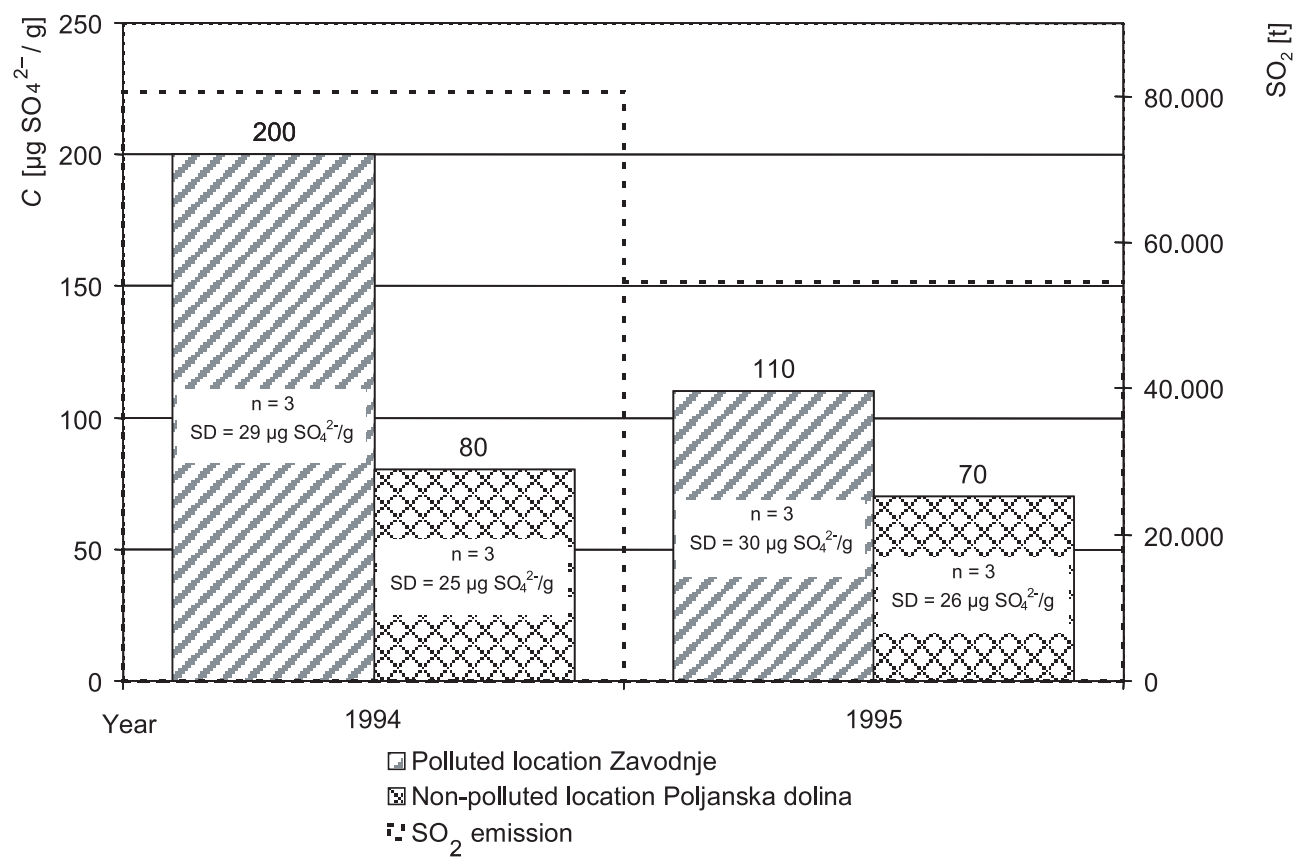

Figure 2. The amounts of $\mathrm{SO}_{4}{ }^{2-}$ determined in samples of honey collected in seasons 1994 and 1995 from a polluted location and a non-polluted location compared to the total emission of $\mathrm{SO}_{2}$ (as determined by electronic monitoring) in these years.

well with the decrease observed by an electronic monitoring.

The excellent response of the bee monitoring system on the emissions of $\mathrm{SO}_{2}$ is presented in Figure 3, which presents a mean, highest and lowest amount of the sulphate determined in the samples of honey taken in the net of apiaries over 8 years of continuous monitoring against the total yearly emissions of $\mathrm{SO}_{2}$ in these years.

Large decreases observed in the mean and highest amounts of determined sulphate in honey from 1994 to 1995 and from 2000 to 2001 as indicated in Figure 2 are due to the operation of exhaust gas purifying facilities at B4 unit (in 1995) and B5 unit (in 2001).

The resulting mean amounts of sulphate determined in honey were plotted against total yearly emissions of $\mathrm{SO}_{2}$ and a straight line was fitted to the measured points by the least square method (Fig. 4).

The regression coefficient (R) (Fig. 4) indicates the mean amounts of sulphate from the influenced area correlated with the total yearly emissions of $\mathrm{SO}_{2}$. The intercept of the derived least-squares line is at $24 \mu \mathrm{g} \mathrm{SO}_{4}^{2-} / \mathrm{g}$ which represents the amount of sulphate in honey at no $\mathrm{SO}_{2}$ emission. The result is in agreement with the literature (Schuette and Triller, 1938) and comparable to the lowest amount of sulphate we determined in the honey from the observed area what shows that the amounts of sulphate in honey are dependent on the $\mathrm{SO}_{2}$ emissions. In addition the figure indicates that obtained data could be divided into three groups according to the criteria of working purifying facilities.

\section{ACKNOWLEDGEMENT}

We are grateful to Ms. Marija Toplak and Ms. Mira Zupančič for assistance. We gratefully acknowledge to the Power Plant Šoštanj, the local communities Velenje, Šštanj and Šmartno ob Paki and Ministry of Education, Science and Sport of the Republic of Slovenia for the financial support. 


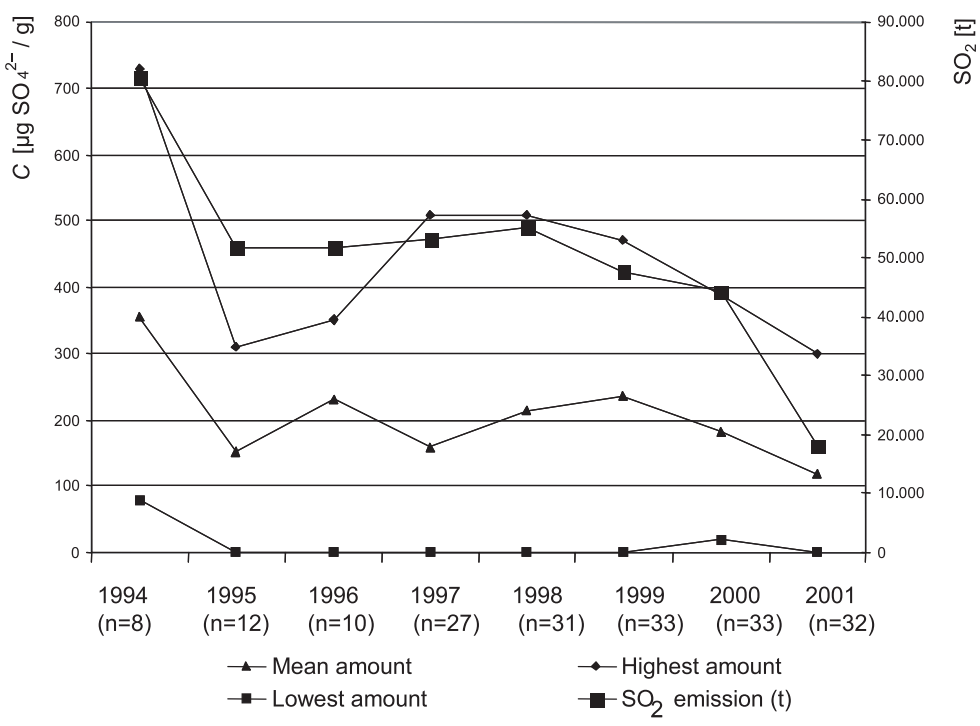

Figure 3. The mean, highest and lowest sulphate amount determined in honey from the observed area surrounding the Šsstanj power plant over 8 years of continuous monitoring in comparison to the total yearly emission of $\mathrm{SO}_{2}$ as determined by electronic monitoring.

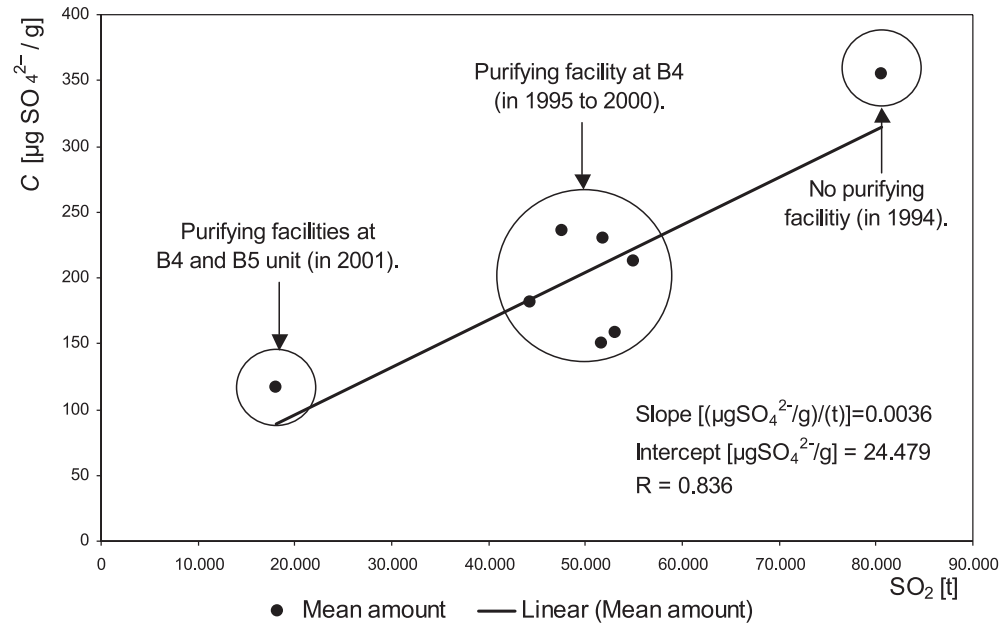

Figure 4. The mean amounts of sulphate determined in honey plotted against total yearly emissions of $\mathrm{SO}_{2}$ and a straight line obtained by the least square method.

Résumé - Le miel, indicateur biologique de la pollution de l'environnement par le $\mathrm{SO}_{2}$. Les abeilles domestiques (Apis mellifera L.) et leurs produits ont été utilisés pour suivre la répartition et l'impact de divers polluants de l'environnement. Les résultats de notre étude montrent que la quantité de sulfates dans le miel est un paramètre fiable pour estimer la pol- lution par le $\mathrm{SO}_{2}$. Un réseau de surveillance de 32 ruchers pré-existants a été configuré dans les environs de la centrale électrique de Šoštanj en fonction des directions du principal transport de pollution et de la densité d' habitants dans une surface couvrant environ $700 \mathrm{~km}^{2}$. L'influence de la centrale sur l'environnement a aussi été simultanément suivie 
par un système électronique de surveillance constitué de sept stations mesurant en continu les concentrations en $\mathrm{SO}_{2}$ et en $\mathrm{NO}_{2}$ et les données météorologiques. La réaction du réseau d'abeilles aux émissions de $\mathrm{SO}_{2}$ a été testée avant et après que les dispositifs de purification des gaz d'échappement aient été mis en action. On a détecté une diminution de la quantité de sulfates dans le miel provenant de la zone étudiée. Cette diminution correspondait à celle observée avec le système de surveillance électronique (Fig. 4). Ce type de programme de surveillance pourrait s'appliquer à n'importe quel autre type de pollution de l'environnement. Par l'utilisation de diverses techniques analytiques, il pourrait être également possible de surveiller d'autres polluants d'origine organique ou non. Il faut signaler que les quantités de sulfates détectées dans les miels de cette étude sont négligeables du point de vue de consommateur.

miel / indicateur biologique / pollution / $\mathrm{SO}_{2} /$ contrôle biologique

Zusammenfassung - Honig als Bioindikator für Umweltverschmutzung mit $\mathbf{S O}_{2}$. Honigbienen (Apis mellifera L.) und ihre Erzeugnisse wurden zur Überwachung der Ausbreitung und Auswirkung verschiedener Umweltschadstoffe eingesetzt. Unsere Untersuchungen konnten zeigen, dass der Sulphatgehalt im Honig ein verlässlicher Parameter zur Bestimmung der Umweltverschmutzung mit $\mathrm{SO}_{2}$ ist. Ein Überwachungsnetz von 32 bereits vorhandenen Bienenständen wurde in der Umgebung des Šoštanj Kraftwerks ausgewählt. Gesichtspunkt war die Hauptrichtung für die Verbreitung der Verschmutzung durch Gasausstoß und die Bevölkerungsdichte in einem etwa $700 \mathrm{~km}^{2}$ Gebiet. Die Auswirkung des Kraftwerks auf die Umgebung wurde gleichzeitig mit einem elektronischen Messsystem bestimmt, das aus 7 stationären Messstellen für Immissionen bestand. Diese maßen kontinuierlich neben $\mathrm{SO}_{2}$ und $\mathrm{NO}_{\mathrm{x}}$ Konzentrationen auch meteorologische Daten. Die Reaktion des Überwachungsnetzes mit Bienen auf $\mathrm{SO}_{2}$ Emissionen wurde vor und nach dem Einbau eines Filters zur Reinigung der Abgase getestet. Die Abnahme der Sulphatmenge im Honig in der Testzone korrespondierte mit den Daten der elektronischen Überwachung (Abb. 4). Diese Art eines Überwachungsprogramms könnte auch in anderen Gegenden mit Umweltverschmutzung angewendet werden. Zusätzlich könnte es möglich sein, unter Anwendung verschiedener analytischer Techniken andere organische oder nicht organische Umweltgifte nachzuweisen.

Zum Schluss sollte betont werden, dass die Sulphatmenge im Honig bei dieser Untersuchung so gering war, dass sie keine Rolle für die Verbraucher spielten.

$\mathrm{SO}_{2}$ / Umweltverschmutzung / Bioüberwachung / Bioindikator / Honig

\section{REFERENCES}

Barišić D., Bromenshenk J.J., Kezič N., Vertačnik A. (2002) The role of honey bees in environmental monitoring in Croatia, in: Devillers J., PhamDelègue M.H. (Eds.), Honey bees: Estimating the environmental impact of chemicals, Taylor \& Francis, London, pp. 160-185.

Bock R. (1979) A handbook of decomposition methods in analytical chemistry, Blackie group, London.

Bromenshenk J.J., Gudatis J.L., Carlson S.R., Thomas J.M., Simmons M.A. (1991) Population dynamics of honey bee nucleus colonies exposed to industrial pollutants, Apidologie 22, 359-369.

Del Nozal M.J., Bernal J.L., Diego J.C., Gómez L.A., Ruiz J.L., Higes M. (2000) Determination of oxalate, sulphate and nitrate in honey and honeydew by ion-chromatography, J. Chromatogr. A 881, 629-638.

Hoopingarner R.A., Waller G.D. (1993) Crop pollination, in: Graham J.M. (Ed.), The hive and the honey bee, Dadant \& Sons, Hamilton, IL, pp. 1043-1082.

Kump P., Nečemer M., Šnajder J. (1996) Determination of trace elements in bee honey, pollen and tissue by total reflection and radioisotope X-ray fluorescence spectrometry, Spectrochim. Acta B 51, 499-507.

Milan Vidmar Elektroinstitute (2001) Annual report on monitoring of the Šoštanj coal-fired thermal power plant, Ljubljana, Slovenia.

Miller J.C., Miller J.N. (1993) Statistics for analytical chemistry, 3rd ed., Prentice Hall, Harlow.

Mooibroek K. (1978) Mettler, Phototitration: A guide to methods, Greifensee.

Ross J.W., Frant M.S. (1969) Potentiometric titrations of sulphate using an ion-selective lead electrode, Anal. Chem. 41, 967-969.

Schuette H.A., Triller R.E. (1938) Mineral constituents of honey III. Sulfur and chlorine, Food Res. 3, 543-547.

Selig W. (1970) Micro and semimicro determination of sulphur in organic compounds by potentiometric titration with lead perchlorate, Mikrochim. Acta 1, 168-175.

Singhal R.S., Kulkarni P.R., Rege D.V. (1997) Handbook of indices of food quality and authenticity, Woodhead Publishing, Cambridge.

Smodiš B., Bleise A. (2002) Internationally harmonized approach to biomonitoring trace element atmospheric deposition, Environ. Pollut. 120, 310.

Vogel A.I. (1978) Vogel's textbook of quantitative inorganic analysis, Longman, London.

White Jr. J.W. (1975) Characteristics of honey, in: Crane E. (Ed.), Honey, Heinemann, London, pp. $158-172$.

Wolterbeek B. (2002) Biomonitoring of trace element air pollution: principles, possibilities and perspectives, Environ. Pollut. 120, 11-21. 